\title{
William A. Hinton (1883-1959): Diagnosing and Confronting Racism in the Medical Profession
}

\author{
Ángel Rodríguez ${ }^{1} \cdot$ M. William Lensch ${ }^{2} \cdot$ Scott H. Podolsky ${ }^{2,3}$ (i) \\ Received: 8 March 2021 / Revised: 30 June 2021 / Accepted: 1 July 2021 / Published online: 20 July 2021 \\ (C) W. Montague Cobb-NMA Health Institute 2021
}

\begin{abstract}
Racism impacts every aspect of medicine, including the careers and lives of Black physicians. The story of William Augustus Hinton (1883-1959), who invented the Hinton Test for syphilis before becoming the first African American full professor at Harvard University in 1949, offers an instructive perspective on the intersection of interpersonal and systemic racism, and personal determination, just over our historical horizon. Yet there are sobering and instructive lessons throughout this history. Hinton had to navigate prejudice throughout his career. Indeed, while there is much to be inspired by in the telling of Hinton's story, the forms of racism faced by Hinton and his contemporaries remain persisting features of academic medicine. This article focuses on encounters with racism that affect the course of medical careers and scientific innovation. Hinton's story holds important implications for many health professionals in the twenty-first century and provides unique insights into the history and impact of interpersonal and systemic racism alike in academic medicine.
\end{abstract}

Keywords William A. Hinton · Racism · Syphilis · Diagnostics · Public health · Massachusetts

\section{Introduction}

Racism impacts every aspect of medicine, including the careers and lives of Black and minority physicians. Black medical students and faculty alike remain under-represented in proportion to US population figures. [1,2] The story of William Augustus Hinton (1883-1959), who invented the Hinton Test for syphilis, offers an instructive perspective on the intersection of interpersonal and systemic racism, and personal determination just over our historical horizon Fig. 1.

\section{Early Life and Career of Dr. William Hinton}

Hinton was born in 1883 in Chicago, IL, after his parents had moved north from North Carolina as emancipated people. They would move again to Kansas, where Hinton would be an early academic achiever and become the youngest to have

Scott H. Podolsky

scott_podolsky@hms.harvard.edu

1 Harvard T.H. Chan School of Public Health, Boston, MA, USA

2 Harvard Medical School, Boston, MA, USA

3 Center for the History of Medicine, Francis A. Countway Library of Medicine, 10 Shattuck St., Boston, MA 02115, USA graduated from his high school. After 2 years at the University of Kansas, and an apparent stoppage in his education owing to a lack of funds, he entered Harvard College in 1903, graduating in 1905. Hinton then spent several years teaching science at historically Black colleges — while also continuing his own studies in bacteriology and physiology-before enrolling at Harvard Medical School (HMS) in 1909. [3-6] He was twenty-eight when he graduated from HMS in 1912 - the only Black student in the graduating class. Hinton pursued a surgical internship but was turned down because of the Jim Crow policies of most American hospitals at the time, both above and below the Mason-Dixon line. [3, 7] Hinton then decided to pursue laboratory work in pathology, a career in which he would not have to compete with white physicians for patients. He cultivated relationships with academic mentors, which remains essential for opportunities and advancement in any professional field. [4] After Hinton's graduation, Dr. Richard C. Cabot, a dear friend and former professor, observed, "He was determined to succeed without benefit of internship which is considered essential for every doctor." [5]

Cabot was also affiliated with the Massachusetts General Hospital Pathological Laboratory where Hinton prepared daily tissue samples and blood examinations. For 3 years, he trained on the Wassermann test for syphilis, invented in 1906. [4, 8] These postgraduate years served Hinton both to advance his knowledge of venereal infections and improve his 


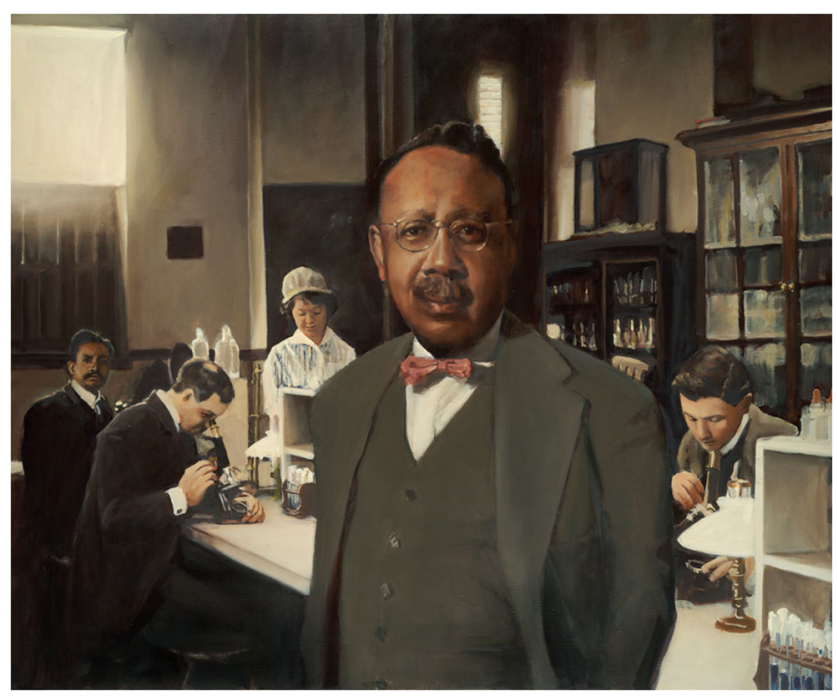

Fig. 1 "Dr. William A. Hinton," Oil on canvas, Harvard University Portrait Collection, Harvard Medical School, 2019. Image used with permission of the artist, Stephen Coit. All rights reserved

practical understanding of the technique for the detection of syphilis. Such dedication and performance apparently earned Hinton an invitation to contribute discussions of the Wassermann reaction to groundbreaking textbooks on preventive medicine by Milton Rosenau and neurosyphilis diagnosis by E.E Southard. ${ }^{1}[4,8-10]$ Hinton's performance was recognized and eventually led to his selection as the Chief of the Wassermann Laboratory of the Massachusetts Department of Public Health in 1915. In the same year, the Laboratory, while operating within the HMS physical space, was formally transferred to state control. He was also named Director of the Laboratory Department at the Boston Dispensary during the same year. $[4,8,11,12]$ By the end of the decade, Hinton's scientific expertise and organizational leadership led to the development and adoption of a standard method for the Wassermann test in Massachusetts. [13]

From 1920 onward, Hinton focused on increasing the capacity of the Wassermann Laboratory to manage a greater output of diagnostic services and scaled up Wassermann testing to meet the growing demand by medical clinics across New England. This also led to a significant modification of the serologic technique that reduced the high rate of discrepancies in syphilis diagnoses. [14-17] By 1935, what had become known as the Hinton Test performed admirably when it

\footnotetext{
${ }^{1}$ Note that while the HMS "memorial minute" describes Hinton as having been invited to write a chapter in Rosenau's textbook, there is no direct attribution of authorship to Hinton in the textbook. Rather, in the revised second edition (1916), Rosenau notes: "The following is a brief description of the Wassermann reaction as carried out for the Massachusetts State Department of Health, by Dr. W.A. Hinton, under my direction" (446). The several-page description (and partial nod to Hinton) would be maintained, with only minor revision, through the fourth edition (1925). Hinton's contributions to the Rosenau and Southard textbooks are listed as the first and third entries in his Curriculum Vitae (though he appears to have mistakenly referenced the $3^{\text {rd }}$ edition of Rosenau as his first contribution to the textbook).
}

was evaluated alongside thirteen other syphilis diagnostics by the United States Public Health Service (USPHS). Among blood samples, Hinton's innovative technique achieved a robust $81 \%$ sensitivity for untreated primary syphilis, $100 \%$ for untreated secondary syphilis, and $84.5 \%$ for treated "late" syphilis, with a $99.3 \%$ specificity among "normal" controls. ${ }^{2}$ [18] In 1935, Hinton was asked to serve as a Special Consultant to the USPHS. [8] And by the late 1930s, national legislative hearings to appropriate Congressional funds toward the control of syphilis prominently featured Massachusetts' syphilis control efforts, which directly informed the Venereal Diseases Control and Prevention Act of 1938, authorizing federal funds to states for such purposes. [19]

In 1936, Hinton summarized the state of syphilology in a medical textbook, Syphilis and Its Treatment, where he clearly described the three stages of syphilis and offered instruction to detect the disease. [20] He prioritized prevention methods over anti-syphilitic treatments - mainly mercury, arsenicals, bismuth, and iodine-based drugs at the time. It was a magnum opus and an important contribution to modern medicine.

Hinton's teachings were widely recognized and highly regarded by medical students and faculty colleagues who witnessed his work. In addition to a paid position at the Massachusetts Department of Public Health, Hinton assisted teaching on venereal disease diagnostics at HMS. [3, 21] In 1923, he was named Assistant in Preventive Medicine and Hygiene at HMS; the following year, he was appointed clinical instructor in Preventive Medicine and Hygiene, as well as in Bacteriology (in 1929, the latter position would transition to Instructor in Bacteriology and Immunology). [4, 8, 22-24] After decades of pioneering research and esteemed teaching, he was finally promoted to Clinical Professor of Bacteriology and Immunology in 1949. A press editorial entitled "No Color Line" featured the promotion and announced, "Last week the Harvard Medical School set a new and admirable precedent by appointing its first Negro professor," Dr. William A. Hinton. [25] Indeed, Hinton was Harvard University's first African American tenured professor in its history. In 2008, the Massachusetts Department of Public Health's State Laboratory Institute was renamed the William A. Hinton State Laboratory Institute. [26] HMS eventually moved to recognize Hinton and installed a portrait of him in September 2019, now on display in the medical school's centrally located Waterhouse Room, alongside former deans and medical luminaries (Fig. 1). [27] A year later, HMS renamed one of its core academic student societies the William Augustus Hinton Society. [28]

\footnotetext{
${ }^{2}$ Among all cases of syphilis studied, Hinton's test thus achieved a combined sensitivity of $86.6 \%$ (354/409), compared to the $78.9 \%$ (4204/5343) overall rate among the thirteen tests studied for blood samples.
} 


\section{Hinton, Race, and Racism}

Hinton's career advancement depended on carefully navigating academic medicine. He entered the medical and public health professions during a time of both overt racism regarding the inherent health status of African Americans, and restricted opportunities for African Americans to enter the medical workforce. [29] Along these lines, Hinton's choice of laboratory work over clinical practice in a white environment may have helped him escape some racial encounters he would have confronted elsewhere. Yet throughout his career, Hinton made multiple efforts to obscure his racial identity from his medical research. [6] It is striking that Hinton instructed and published extensively on the problem of syphilis, given the prevailing medical associations made between syphilis and racial pathology in the first half of the twentieth century. Medical authorities would invoke both biological determinism and apparent Black hypersexuality to explain syphilis rates and outcomes among African Americans in the first decades of the twentieth century. [30] Such assumptions, predicated on notions of difference, would of course culminate in the Tuskegee Syphilis Study, beginning in 1932. [31] Despite such prevailing concerns, in the 321 pages of Hinton's Syphilis and Its Treatment, a mere single reference is made regarding the Black community and syphilis: "There is experimental evidence that trauma may increase the size of an existing syphilitic lesion in animals," Hinton stipulated, “... and doubtless this often occurs in human beings. It may in this way account for the high rate of cardiovascular syphilis in Negroes who, as a class, do physical labor which taxes the heart and blood vessels." [20 , p. 86] Could it have been, or could Hinton have thought, that more references to race by him would have jeopardized his professional advancement and academic aspirations?

There was at least one counterexample of a contemporary Black physician who held a position at a white university and who focused on the issue of race in medicine. Julian Herman Lewis, M.D., Ph.D., professor of pathology at the University of Chicago, published The Biology of the Negro in 1942. [32] Drawing on his background as both a doctor and recipient of a $\mathrm{Ph}$.D. in physiology and pathology, Lewis demonstrated that claims of Black inferiority had no basis in the science of biology. Lewis' insights were part of a broader body of antiracist research aimed at challenging the very idea of race and its perceived nature as a biological category. [33]

The issue of race appears to have been complicated for Hinton. In 1932, in discussing a potential article on Hinton for The Crisis, the leading journal of the National Association for the Advancement of Colored People (NAACP), W.E.B. Du Bois noted: "It is a disgrace to have colored people know so little about his work. Moreover, I believe the Spingarn medal [which since 1915 has been awarded by the NAACP to recognize outstanding achievement by a person of African descent and American citizenship] committee would be glad to consider him for the Spingarn Medal for 1931." [34] Yet Hinton's "modesty" apparently made him resistant to being featured in the journal. [35] As Du Bois surmised: "He not only has scientific modesty, but it is possible that he would not be willing to have his color stressed." [36] Six years later, at the height of Hinton's medical career, the NAACP indeed selected Hinton to be the recipient of the Spingarn Medal. Yet Hinton turned down the Award, making 1938 the first year since the inception of the award that there was no recipient. He later claimed during a special feature on his medical career in Ebony magazine that drawing attention to his racial identity would have negatively impacted the acceptance of his scientific research by the medical profession, especially in the South. [37] Whether Hinton's claim was true or a projection on his part, it appears to have had the effect of moving him to decline the Award - a symbol of Black pride for many African Americans then and now.

William A. Hinton was not outspoken about racism and its impacts throughout his lifetime. Nevertheless, whatever sense of racial identity he might or might not have had throughout his life and career as a medical professional, the outside world saw and treated him as a Black physician. Hinton's biography, in this reading, characterizes relentless determination for twenty-first century graduate students and physicians who likewise aspire to advance medical innovation in the face of racial inequality.

\section{Confronting Racism in Medical Education}

There are other lessons to be derived from Hinton's story, concerning the enduring roles of interpersonal and institutional racism alike. Few medical colleges have engaged with the deeply embedded racism, historical and contemporary, that shapes the learned and lived experiences of students and educators of color. The decision to rename what would become the William Augustus Hinton Society did not take place in a vacuum, but rather occurred in the context of the COVID-19 pandemic outbreak and Black Lives Matter movement, and several years after the inception of White Coats for Black Lives [38]. The Society had originally been named the Oliver Wendell Holmes Society in 1982, memorializing the nineteenth century physician, author, and educator, who had written in 1843 of the contagiousness of puerperal fever, and who had played a central role in placing American medicine and especially therapeutics on a rational footing. [39, 40] Yet as HMS Dean in 1850, Holmes had admitted the school's first three African American students, only to expel them later that same academic year in response to white student protest. In the summer of 2020, HMS and Harvard School of Dental Medicine (HSDM) students organized and petitioned to rename the Society. [41] In response, HMS leadership asked 
its Subcommittee on Artwork and Cultural Representations to deliberate not only on the renaming of the Holmes Society, but on the "guiding principles concerning why we name features across our campus and under what circumstances we might consider changing an eponymous feature." [42] The committee concluded that such features serve as a source of inspiration, as a symbol of the school's collective aspirations, and as an opportunity to communicate its values to the world around it and especially to its own staff, students, and faculty. On September 23, 2020, the Oliver Wendell Holmes Society was officially renamed the William Augustus Hinton Society at Harvard Medical School. Where students had led the way for racial exclusion in 1850, HMS/HSDM students charted anti-racist pathways and reconciliation efforts in 2020 . Whereas leadership had responded in 1850 by expelling three Black students, leadership in 2020 declared itself committed not only to diversity and inclusion, but to combatting centuries of racism and its impacts at HMS/HSDM and beyond.

The new Hinton Society is a symbolic step toward addressing diversity, inclusion, and equity, with inclusive excellence as a foundation. Yet to truly address the reality of racism more concretely, medical schools will have to address the impacts of wider structural inequality. A coda to the Hinton story is perhaps instructive. As noted earlier, in response to Hinton's promotion to full professor in 1949, the Boston Sunday Herald trumpeted the headline, "No Color Line," noting that the "superb accomplishments of Dr. Hinton simply shame the drawers of the color line." [25] The editorial was unsigned and noted, "The event will occasion general satisfaction, but it will be particularly heartening to young Negroes now preparing to launch themselves on a professional career. There is a tremendous need for adequately trained doctors today, but many Negroes have been discouraged from entering this field because of the still strong barriers of prejudice." The editorial then acknowledged both the structural and interpersonal forms of racism serving to generate existing disparities in the representation of African Americans in medicine, lamenting: "One of the chief reasons for this gap, of course, was and is economic. Negroes on the average have had smaller incomes than whites and have been less able to finance costly professional training. But there have been other handicaps, too. Many schools have not welcomed Negroes, internship opportunities have been restricted, and hospitals have been chary of admitting Negro doctors for practice." But the editorial continued in a cheery, and in retrospect, grossly over-optimistic vein, noting: "Massachusetts, happily, ranks among the least raceconscious states. ... We still have a long way to go in the elimination of meaningless prejudices, but recent months have witnessed great progress."

In 1969, just more than a decade after the passing of William Hinton, prominent HMS faculty rendered a more sober assessment regarding such "progress" in academic medicine, in particular reflecting on the history leading to the school's affirmative action plan initiated a year earlier in the wake of the assassination of Martin Luther King, Jr. and the findings of the Kerner Commission. Psychiatrist Leon Eisenberg, Chairman of the School's Commission on Relations with the Black Community and later inaugural Chair of the Department of Social Medicine, took pains in this setting to highlight structural racism, rather than interpersonal racism, as the key force with which efforts to reduce racial disparities in academic medicine would need to reckon: "There is no evidence that members of present or previous [HMS] admission committees exercised conscious bias against - and some even maintain having had a preference for-'qualified' black students." Rather, academic medicine had collectively failed to address the structural barriers to increasing the representation of African Americans within its programs. As Eisenberg continued: "All of us have tolerated, if we have not created, a social structure whose outcome has been racist, whether it was consciously intended or not. To the victim, it has mattered little whether the outcome was intended." [43]

Half a century later, society and medicine alike have seemingly rediscovered the impact of not only the interpersonal racism experienced by Hinton, but of structural racism on a host of outcomes, including medical education and advancement. Tellingly, over the past four decades, Black female enrollment in US medical schools has only marginally increased (from 3.6 to $4.4 \%$ ), while Black male enrollment has actually decreased (from 3.1 to $2.9 \%$ ). [1] There remains a tremendous need for more well-trained Black doctors and faculty today, and for efforts to engage with existing barriers to entry, retention, and advancement across the academic life cycle. Amidst such persisting inequities, proposed solutions have ranged from investing in the "pipeline" of African American students well before the medical school application process, through more holistic and enlightened admissions policies, the reduction of microaggressions at every stage of medical education (from the interview process onward), the diversification of faculty and imagery alike at medical schools, improving the mentorship and support of minority students and faculty, and applying thoughtful attention (and solutions) to the "minority tax" increasingly borne by faculty of color as medical schools attempt to engage with such legacies of racism. [2, 44-47] Hinton's story, and the persistence of interpersonal and structural racism decades after his own death, serve both as a source of inspiration and as a spur to ongoing selfexamination as we continue to confront racism in all its forms.

Acknowledgements The authors would like to acknowledge the input and support of Dr. Kenneth Manning, Thomas Meloy Professor of Rhetoric and of the History of Science, Massachusetts Institute of Technology; Mr. Stephen Coit, official artist of the Harvard Foundation Portraiture Project; Jessica Murphy, Public Services Librarian, Center for the History of Medicine, Francis A. Countway Library of Medicine; Dr. 
Joan Reede, Dean for Diversity and Community Partnership at Harvard Medical School; and Dr. Alfred DeMaria.

\section{Declarations}

Conflict of Interest The authors declare no competing interests

\section{References}

1. Morris DB, Gruppuso PA, McGee HA, Murillo AL, Grover A, Adashi EY. Diversity of the national medical student body-four decades of inequities. N Engl J Med. 2021;384:1661-7.

2. Nivet MA. Minorities in academic medicine: review of the literature. J Vasc Surg. 2010;51(4 Suppl):S53-8.

3. Nabrit, BA Question of merit: a study of William Augustus Hinton. Undergraduate thesis: The Committee of History and Science. Harvard University, Cambridge MA; 1972.

4. Coons AH, Davies JAV, Davis BD, Rivers FE, Enders J. William A. Hinton [Memorial Minute]. Harvard University Gazette Vol. LV. No. 39, July 16, 1960.

5. Merit not Race: Postcard from Canton, Massachusetts. Canton Historical Society, December 15, 2015. https://cantonhistory. blogspot.com/2015/. Accessed 6 Mar 2021.

6. Munson E. Biographical feature: William A. Hinton, M.D. J Clin Microbiol. 2020;58:e1933-20.

7. Worthy W. An appreciation of Dr. Hinton [correspondence]. N Engl J Med. 1952;247:453.

8. Curriculum Vitae, William Augustus Hinton, located in "William A. Hinton," Biofile Collection, Center for the History of Medicine, Francis A. Countway Library of Medicine.

9. Rosenau MJ. Preventive medicine and hygiene. 2nd ed. D. Appleton and Company: New York, NY; 1916.

10. Southard EE, Solomon HC. Neurosyphilis: modern systematic diagnosis and treatment presented in one hundred and thirty-seven case histories. Boston: W.M. Leonard; 1917.

11. Haydon RC. Hinton, William Augustus, 1883-1959: African American physician and clinical pathologist. In Appiah KA, Gates HL, Jr., eds. Africana: the encyclopedia of the African and African American experience, volume 3. New York: Oxford University Press, 215-216.

12. Black PR. Two Black alumni overcoming racial barriers. Harvard Medical Alumni Bulletin. Summer 1989;63:38-42.

13. Hinton WA. Standardized Wassermann technique: state approved Wasserman laboratories. Commonhealth. 1918;5(12):374-81.

14. Hinton WA. A Glycerol-cholesterol precipitation reaction in syphilis. N Engl J Med. 1927;196:993-6.

15. Hinton WA, Stuart GO. The Hinton glycerol cholesterol agglutination reaction: modifications in technic (second communication). J Lab Clin Med. 1929;14:621-4.

16. Hinton WA, Berk A. The Hinton glycerol cholesterol reaction for syphilis: second modification. N Engl J Med. 1930;202:1054-9.

17. Hinton WA. Hinton test for syphilis: third modification. J Lab Clin Med. 1932;18:198-205.

18. Cumming HS, Hazen HH, Sanford AH, Senear FE, Simpson WM, Vonderlehr RA. The evaluation of serodiagnostic tests for syphilis in the United States: report of results. JAMA. 1935;104:2083-7.

19. Hearings before a subcommittee of the Committee on Commerce United States Congress. Third session on S.3290. Investigation and Control of Venereal Diseases. February 14, 1938.

20. Hinton WA. Syphilis and its treatment. Macmillan: New York; 1936.
21. Announcement of the Medical School of Harvard University for 1922-1923 (course catalogue), located in Center for the History of Medicine, Francis A. Countway Library of Medicine.

22. Announcement of the Medical School of Harvard University for 1923-1924 (Course Catalogue), located in Center for the History of Medicine, Francis A. Countway Library of Medicine.

23. Announcement of the Medical School of Harvard University for 1924-1925 (Course Catalogue), located in Center for the History of Medicine, Francis A. Countway Library of Medicine.

24. Announcement of the Medical School of Harvard University for 1929-1930 (Course Catalogue), located in Center for the History of Medicine, Francis A. Countway Library of Medicine.

25. "No Color Line." Boston Sunday Herald, July 3, 1949. Located in "William A. Hinton," Biofile Collection, Center for the History of Medicine, Francis A. Countway Library of Medicine.

26. State Lab Dedicated to Dr. William Hinton. Baystate Banner, Volume 43, Number 38, May 1, 2008. http://www.baystatebanner.com/issues/2008/05/01/news/health05010823.htm\#: *text= Hinton\%2C\%20the\%20first\%20African\%20American,William\% 20A. Accessed 6 Mar 2021.

27. Buckley MRF. Portrait of a pioneer. News and research, Harvard Medical School. https://hms.harvard.edu/news/portrait-pioneer. Accessed 6 Mar 2021.

28. Buckley MRF. Winds of change. News and research, Harvard Medical School. https://hms.harvard.edu/news/winds-change. Accessed 6 Mar 2021.

29. Gamble VN. "There wasn't a lot of comforts in those days": African Americans, public health, and the 1918 influenza epidemic. Public Health Rep 2010; 125 (suppl. 3): 113-122.

30. Murrell TW. Syphilis in the American Negro: a medico-sociologic study. JAMA. 1910;54:846-9.

31. Reverby SM. Examining Tuskegee: the infamous syphilis study and its legacy. Chapel Hill: University of North Carolina Press; 2009.

32. Lewis JH. The biology of the Negro. Chicago: University of Chicago Press; 1942.

33. Crenner C. Race and laboratory norms: the critical insights of Julian Herman Lewis (1891-1989). Isis. 2014;105:477-507.

34. Du Bois, W. E. B. (William Edward Burghardt), 1868-1963. Letter from W.E.B. Du Bois to Louis Wright, January 19, 1932. W.E.B. Du Bois Papers (MS 312). Special Collections and University Archives, University of Massachusetts Amherst Libraries. Digital Permalink $=$ http:credo.library.umass.edu.view.full/mums312b193-i267.

35. Rivers, Francis E. Letter from Francis E. Rivers to W.E.B. Du Bois, February 5, 1932. W.E.B. Du Bois Papers (MS 312). Special Collections and University Archives, University of Massachusetts Amherst Libraries. Digital Permalink $=$ http:credo.library.umass edu.view.full/mums312-b063-i448

36. Du Bois, W.E.B. (William Edward Burghardt), 1868-1963. Memorandum from W.E.B. Du Bois to N.A.A.C.P. Spingarn Medal Award Committee, February 24, 1932. W.E.B. Du Bois Papers (MS 312). Special Collections and University Archives, University of Massachusetts Amherst Libraries. Digital Permalink = http:credo.library.umass.edu.view.full/mums312-b063-i103.

37. Race brought rejection of Hinton syphilis test. Ebony, October 1955; 66-68.

38. Charles D, Himmelstein K, Keenan W. Barcelo N, for the White Coats for Black Lives National Working Group, "White coats for Black lives: medical students responding to racism and police brutality,". J Urban Health. 2015;92:1007-10.

39. Drew LW. Inside H.M.A.B. Harvard Medical Alumni Bulletin, Winter 1984; 58:2.

40. Podolsky SH, Bryan CB. Oliver Wendell Holmes: Physician and Man of Letters. Sagamore Beach: Science History Publications; 2009. 
41. Renaming Holmes Society at HMS/HSDM. https://docs.google. com/forms/d/e/1FAIpQLSeGz-HFs9NGE1vQxGSuAbaJQh_ LRap8jzkvNadrtL1PtrMX-A/viewform. Accessed 6 Mar 2021.

42. Dean George Q. Daley to Members of the HMS and HSDM community, September 23, 2020, http://links.mkt3779.com/servlet/ $\mathrm{M}$ a i $1 \mathrm{Vi}$ e w ? $\mathrm{m} \mathrm{s}=\mathrm{M} \mathrm{j} \mathrm{M} 4 \mathrm{Mzk} 1 \mathrm{O}$ D I S $1 \& \mathrm{r}=$ MjY5MzYyOTcyNTM2S0\&j=MTgyMTQwMjk5NQS2\&mt= $1 \& \mathrm{rt}=0$. Accessed 6 Mar 2021.

43. Leon Eisenberg (Chairman, Commission on Relations with the Black Community) to Robert H. Ebert, 4/1/69, as introduction to "Preliminary Report of the Commission on Relations with the Black Community," submitted to the Faculty of Medicine, April 11, 1969, Box 2, file folder 2, Leon Eisenberg Papers, H MS c196, Francis A. Countway Library of Medicine.
44. Forrester A. Why I stay - the other side of underrepresentation in academia. N Engl J Med. 2020;383:e24. https://doi.org/10.1056/ NEJMpv2022100.

45. Owoseni AV. From portraits to role models - why we need Black physicians in academic medicine. N Engl J Med. 2020;383:2204-5.

46. Ellis J, Otugo O, Landry A, Landry A. Interviewed while Black. N Engl J Med. 2020;383:2401-4.

47. Williamson T, Goodwin CR, Ubel PA. Minority tax reformavoiding overtaxing minorities when we need them most. N Engl J Med. 2021;384:1877-9.

Publisher's Note Springer Nature remains neutral with regard to jurisdictional claims in published maps and institutional affiliations. 